\title{
Bungi : Desa Berkembang di Pinrang 1980-2012
}

Muhammad Yusuf', Muhammad Saleh Madjid ${ }^{2}$, Patahuddin ${ }^{3}$

Prodi Pendidikan Fakultas Ilmu Sosial UNM

Email: mhmmdyusuf2180@gmail.com, salehmadjid@unm.ac.id, patahuddin@unm.ac.id

\begin{abstract}
Abstrak
Penelitian ini bertujuan untuk mengetahui perkembangan Desa Bungi Kecamatan Duampanua Kabupaten Pinrang sejak tahun 1980 sampai 2012. Terbentuknya Desa Bungi sejak diberlakukannya Undang-Undang Desa Tahun 1979. Setelah terbentuk menjadi desa terlihat telah ada beberapa perubahan dan perkembangan baik dalam bidang pemerintahan, bidang pendidikan, bidang ekonomi, bidang kesehatan dan bidang sosial yang berdampak bagi masyarakat Desa Bungi. Penelitian ini adalah penelitian sejarah dengan menggunakan metode sejarah yang melalui beberapa tahapan yaitu, heuristik, kritik sumber, interpretasi dan historiografi. Metode pengumpulan data dilakukan dengan cara wawancara (Bapak Drs. Alhusari Latif mantan kepala desa dan tokoh masyarakat Desa Bungi), Masyarakat Desa Bungi yaitu Muslimin Thamrin, Nasir Mansur S.Kep.Ns) dan mengumpulkan sumber arsip (BPS Kabupaten Pinrang dan Sumber arsip daerah).
\end{abstract}

Kata Kunci: Bungi, Duampanua, Perkembangan

\begin{abstract}
This study aims to determine the development of Bungi village, Duampanua Sub-district, Pinrang regency from 1980-2012. The village of Bungi was formed since the enactment of the village law of 1979. After being formed into a village, there were some changes and developments both in the field of government, education,economiy, the health sector and the social sector that has an impact on the people of Bungi village. This research is a historical research using historical methods which go through several stages namely Heuristics, verification, interpretation and historiography. The data collection method was carried out by interviewing (Drs. AlhusariLatif as a Headman of Village and public figure of Bungi are Musliminthamrin, Nasir Mansur S.Kep.Ns) and collecting archive source (BPS of Pinrang Regency and archive source area.
\end{abstract}

\section{Keywords: Bungi, Duampanua, Development}

\section{A. Pendahuluan}

Indonesia merupakan negara kesatuan yang berbentuk republik dan menganut asas desentralisasi dengan memberikan keleluasaan kepada daerah untuk menyelenggarakan otonomi daerah. Dalam penyelenggaraan pemerintahannya daerah Indonesia terdiri atas beberapa daerah wilayah provinsi dan setiap daerah/wilayah provinsi terdiri atas beberapa daerah kabupaten/kota. Selanjutnya dalam tiap daerah kabupaten/kota terdapat satuan pemerintahan terendah yang disebut desa dan kelurahan. (Haris, 2005)

Desa sebagai satuan pemerintahan terendah mempunyai kedudukan yang sangat penting sebagai alat untuk mencapai tujuan pembangunan nasional ataupun sebagai lembaga yang memperkuat struktur pemerintahan negara Indonesia. Desa sebagai alat untuk mencapai tujuan pembangunan nasional, merupakan wakil pemerintah yang berada di posisi terdepan yang menjangkau masyarakat yang ingin disejahterakan. Oleh karena itu sejak 
Indonesia merdeka keberadaan desa mendapat perhatian oleh pemerintah, hal ini dapat dilihat dengan beberapa kali pemerintah mengeluarkan Undang-Undang yang mengatur tentang desa.

Desa Bungi merupakan salah satu desa yang ada di wilayah Kecamatan Duampanua, Kabupaten Pinrang, Sulawesi Selatan dan berada kurang lebih $34 \mathrm{Km}$ dari ibukota kabupaten dan $10 \mathrm{Km}$ dari ibukota kecamatan. Desa Bungi memiliki luas wilayah $7,61 \mathrm{Km}^{2}$ yang terdiri atas 4 dusun, 16 RT, 8 RW dengan jumlah penduduk sebanyak 4028 jiwa (Subaedah, Patahuddin, \& Najamuddin, 2018). Awalnya, Desa Bungi merupakan suatu wilayah yang bernama Kampung Bungi dan merupakan pusat pemerintahan dari kerajaan Batulappa. Kemudian Kampung Bungi digabung dengan Kampung Maroneng, Kampung Kamali dan Kampung Pasulengang menjadi Desa Bungi. Sejak diberlakukannya UndangUndang Desa Tahun 1979 Desa Bungi telah mengalami berbagai perubahan dan perkembangan di bidang pemerintahan, ekonomi, sosial serta sarana dan prasarana dibanding 9 desa lainnya yang ada di Kecamatan Duampanua.

\section{B. Metode Penelitian}

Metode dapat juga diartikan sebagai suatu prosedur, proses, atau tekhnik yang sistematis. Dalam penulisan ini metode yang digunakan adalah metode sejarah yang merupakan metode khusus dalam penelitian sejarah. Metode Sejarah dapat diartikan sebagai cara atau prosedur yang sistematis dalam merekonstruksi masa lampau (Syamsuddin, 1999). Adapun tahapan-tahapannya sebagai berikut

\section{Heuristik}

Heuristik merupakan tahapan awal dalam melakukan penelitian sejarah. Pada tahap ini sumber-sumber data sejarah terkait dengan topik yang dikaji dikumpulkan. Dalam melakukan pengumpulan sumber, terdapat dua cara yang dapat dilakukan, yaitu penelitian pustaka dan penelitian lapangan. Penelitian lapangan adalah kegiaatan mengumpulkan data secara langsung di lapangan atau lokasi penelitian dalam hal ini Desa Bungi Kecamatan Duampanua Kabupaten Pinrang dengan cara observasi dan wawancara. Sedangkan penelitian pustaka adalah langkah pengumpulan sumber dengan jalan mencari buku-buku dan sumber arsip yang memiliki kaitan dengan judul yang akan dikaji.

\section{Kritik Sumber}

Kritik Sumber merupakan tahapan kedua setelah proses pengumpulan sumber telah dilakukan. sumber yang telah diperoleh harus melalui tahapan kritik sumber untuk menguji keaslian sumber dan tingkat kebenaran informasi.

Adapun pengujian atas asli dan tidaknya sumber berarti yang diuji adalah aspek fisik sumber sejarah. penentuan keaslian suatu sumber berkaitan dengan bahan yang digunakan dari sumber tersebut atau disebut sumber eksternal. Sedangkan dalam penyelesaian informasi yang terkandung dalam sejarah, dapat dipercaya atau tidak, dimana dapat dikenal dengan istilah kritik internal.

\section{Intrepretasi}

Intrepretasi merupakan tahapan ketiga setelah melalui kritik sumber. Pada tahap ini penulis mencoba menghubungkan faktafakta yang telah diperoleh berdasarkan urutan kronologis peristiwa. Pada tahap ini dituntut kecermatan dan sikap objektif sejarawan terutama dalam hal interpretasi terhadap fakta sejarah.

\section{Historiografi}

Historiografi adalah Tahap terakhir dalam penelitian sejarah yaitu penulisan (historiografi) setelah melalui tiga proses sebelumnya, dalam hal ini adalah penulisan sejarah. Penulisan sejarah merupakan proses penjelasan dari semua kegiatan dalam penelitian sejarah.

\section{Tinjauan Penelitian}

Kondisi geografis merupakan salah satu faktor yang sangat penting dan mempengaruhi aktivitas kehidupan masyarakat suatu daerah. Oleh karena itu, 
untuk menganalisis suatu permasalahan pada suatu daerah maka objek analisis tidak lepas dari usaha untuk mengetahui secara lengkap tentang lokasi dan pengembangan daerah tersebut.

Desa Bungi merupakan salah satu desa yang berada wilayah administratif Kecamatan Duampanua. Secara geografis Desa Bungi berada di sebelah Utara dari ibu kota kecamatan, dengan luas wilyahnya 7,61 Km². Desa Bungi berjarak $10 \mathrm{Km}$ dari Kelurahan Lampa yang merupakan ibu kota Kecamatan Duampanua dan $34 \mathrm{Km}$ dari Kota Pinrang (Subaedah et al., 2018).

Desa Bungi memiliki 3 dusun, yaitu Dusun Bungi, Dusun Bajeng Kaluku dan Dusun Susbater. Desa Bungi termasuk wilayah dataran rendah karena berada di ketinggian $<500 \mathrm{M}$ dari permukaan laut. Adapun batas-batas wilyahnya adalah sebgai berikut:

1. Sebelah Utara berbatasan dengan Kecamatan Lembang,

2. Sebelah Timur berbatasan dengan Desa Buttu Sawe,

3. Sebelah Barat berbatasan dengan Desa Maroneng,

4. Sebelah Selatan berbatasan dengan Desa Barugae.

Keadaan topografi Desa Bungi yang merupakan dataran rendah dan berada didekat daerah pesisir sehingga sebagian sebagian wilyahnya digunakan sebagai tambak, lahan pertanian dan perkebunan. Komposisi lahan yang ada di Desa Bungi, yaitu untuk lahan sawah seluas 315,5 Ha, lahan kering 342,75 $\mathrm{Ha}$ dan lahan basah 104,00 Ha. (Badan Pusat Statistik, 2013) Letak Desa Bungi cukup strategis karena dilalui oleh jalan poros lintas provinsi yang menghubungkan Provinsi Sulawesi Selatan dengan Provinsi Sulawesi Barat.

\section{Pembahasan}

1. Perkembangan Desa Bungi 1980-2012.

a. Bidang Pemerintahan

Desa sebagai kesatuan wilayah yang dihuni oleh sejumlah penduduk dan memepunyai pemerintahan sendiri (kepala desa). Dalam pemerintahan apapun termaksuk dalam pemerintahan desa, selalu terdapat beberapa orang yang memiliki kekuasaan tertentu. Sumber kekuasaan itu dapat beraneka ragam, biasanya yang memiliki peranan penting dalam masyarakat. Terpilihnya sebagai pemimpin karena memeliki wibawa pribadi yang baik atau memiliki pengetahuan dan informasi yang tidak dimiliki oleh orang lain. Sejak ditetapkannya Undang-Undang No. 5 Tahun 1979 maka desa mulai mendapat dasar aturan yang jelas tentang pelaksanaan pemerintahan desa (No, 5AD). Kepala desa merupakan pimipinan penyelenggaraan pemerintahan desa. Kepala desa merupakan struktur terendah atau terbawah dari pemerintahan negara, maka ia merupakan aparat negara yang dekat dengan masyarakat. Kepala desa berperan penting dalam perkembangan dari desa yang menjadi tanggung jawabnya. Dalam kurun waktu 1980-2012 Desa Bungi telah dipimpin oleh beberapa kepala desa yaitu sebagai berikut:

\section{Syamrohi (1980-1984)}

Beliau merupakan kepala desa yang menjabat sebelumnya. Pada masa kepemimpinan beliau UU No 5 Tahun 1979 di tetapkan sehingga terjadi perubahan sistem pemerintahan di Desa Bungi.

\section{Lahodding (1984-1987)}

Lahodding adalah kepala Desa Bungi yang mejabat hanya selama 3 tahun. Pada tahun 1985 di Desa Bungi sudah ada beberapa rumah yang sudah dialiri listrik.

\section{Muh djafar.(1987-1989)}

Muh djafar adalah pejabat kepala Desa Bungi yang menjabat dari tahun 1987 sampai tahun 1989. Beliau diangkat oleh camat menggantikan kepela desa sebelumnya. Beliau menjabat sebagai kepala desa selama 2 tahun. Pada masa kepemimpinan beliau mulai dipersiapkan rencana pemecahan Desa Bungi menjadi dua desa yaitu, Desa Bungi dan Desa Buttu Sawe.

\section{Muh Amin. P (1989-1997)}

Muh Amin P menjabat kepala desa dari tahun 1989 sampai tahun 1997 melalui 
proses pemeilihan lansung oleh masyarakat. Pada masa awal kepemimpinan beliau di sebagai kepala desa wilyah Desa Bungi sudah dipecah menjadi dua desa yaitu Desa Bungi dan Desa Buttu Sawe dan pada tahun 1993 terjadi lagi pemecahan wilayah Desa Bungi menjadi desa baru yaitu Desa Maroneng. Selain itu beliau juga berfokus pada pembangunan desa berupa pembuatan jalan lorong. Pada tahun 1992 listrik dari Perusahaan Listrik Negara (PLN) sudah masuk Ke Desa Bungi dengan daya 400 watt.

\section{Drs. Alhusari latif (1997-2012)}

Drs. Alhusari latif menjadi kepala desa setelah dilantik pada tanggal 27 desember 1997 menggantikan Muh Amin P. Beliau menjabat kepala desa selama dua periode. Periode pertama yaitu tahun 1997 sampai tahun 2005 dan periode kedua yaitu tahun 2005 sampai tahun 2006. Beliau merupakan kepala desa pertama dari kalangan pemuda. Dimasa kepemimpinannya telah banyak pencapaian yang telah dilakukan yaitu : Pembuatan jalan jalan desa, pengaspalan jalan desa, membuat sarana olah raga berupa lapangan sepak bola, pembuatan irigasi teknis untuk persawahan, pada tahun 2009 diadakan program pemberantasan Buta aksara di Desa Bungi.

\section{b. Bidang Pendidikan}

Pembangunan bidang pendidikan bertujuan untuk mencerdaskan kehidupan bangsa. Pembangunan sumber daya manusia akan menentukan karakter dari pembangunan ekonomi dan sosial masyarakat sehingga diperlukan sarana dan prasarana pendidikan. Ketersediaan sarana belajar sangat diperlukan untuk pendukung proses pembelajaran agar dapat hasil yang maksimal sesuai dengan yang diharapkan.

Sarana pendidikan dari TK ke SMP di Desa Bungi cukup memadai, dengan adanya Taman Kanak-kanak sebanyak 2 buah, sebelum tahun 2004 jumlah Taman Kanak-kanak di Desa Bungi hanya satu dan kemudian pada tahun 2005 didirikan lagi Taman Kanak-kanak yang keduanya berada di Dusun Bungi. Kemudian di tingkatan SD sebanyak lima buah dimana empat SD negeri sudah ada sejak tahun 1977, satu Madrasah Ibtidaiyah dan satu SMP. Tingkatan Sekolah Menengah Atas (SMA) tidak terdapat di Desa Bungi namun terdapat di Kelurahan Lampa yang merupakan Ibukota Kecamatan Duampanua. Selain sarana dan prasarana komponen penting lainnya dalam system pendidikan adalah peserta didik dan pendidik (guru), peserta didik merupakan potensi dasar yang perlu dikembangkan untuk menghasilkan sumber daya manusia yang berkualitas. Peningkatan jumlah peserta didik di tiap jenjang pendidikan menandakan adanya kesadaran masyarakat tentang pentingya pendidikan. Adapun kondisi peserta didik dan guru yang ada di Desa Bungi sebagai berikut.

Jumlah sisiwa SD/MI pada tahun 2004 berjumlah 629 dan terjadi peningkatan pada tahun 2012 berjumlah 676 orang sedangkan jumlah guru SD/MI hanaya mengalami sedikit peningkatan 34 orang pada tahun 2004 ( Badan Pusat Statistik, 2004) menjadi 46 orang pada tahun 2012. Untuk jenjang SMP jumlah siswanya 347 orang pada tahun 2004 dan pada tahun 2012 berjumlah 386 orang sedangkan jumlah guru SMP pada tahun 2004 adalah 16 orang ( Badan Pusat Statistik, 2004) dan pada tahun 2012 mengalami peningkatan menjadi 24 orang. Adapun rasio guru dan murid pada jenjang SD/MI di Desa Bungi pada tahun 2012 adalah 1:14 sedangkan untuk jenjang SMP adalah 1:16. Berdasarkan data tesebut menunjukkan bahwa masyarakat Desa Bungi telah memiliki kesadaran akan pentingnya pendidikan.

\section{c. Bidang Ekonomi}

Sektor pertanian pada desa Bungi merupakan sektor yang paling menonjol, kerena sebagian besar penduduk desa bermata pencaharian sebagai petani. Pada tahun 1980 sampai 1989 luas sawah di Desa Bungi adalah seluas 1200,50 Ha namun setelah Desa Buttusawe dimekarkan maka luas sawah yang ada di Desa Bungi menjadi berkurang. Tercatat Pada tahun 
2004 Desa Bungi memiliki luas lahan sawah yaitu 550 Ha. Kemudian terjadi penyusutan luas sawah pada tahun 2006 menjadi $475 \mathrm{Ha}$ dan berkurang lagi pada tahun 2011 menjadi $315 \mathrm{Ha}$.

Sistem pengairan yang digunakan para petani di Desa Bungi Pada tahun 1980an sampai tahun 2000an masih menggunakan sistem pengairan sawah tadah hujan. Pada tahun 2011 dibuatlah irigasi teknis untuk membantu sistem pengairan para petani. Adapaun luas sawah yang menggunakan Sistem pengairang irigai teknis adalah 77,55 Ha sedangakan 25,00 menggunakan irigasi desa dan 212,70 Ha masih meggunakan sistem tadah hujan (Pinrang, 2017). Sistem pengolahan lahan yang digunakan para petani di Desa Bungi Pada tahun-tahun 1980an sampai tahun 2000 masih menggunakan sistem pengolahan lahan secara tradisional dengan menggunakan hewan ternak seperti sapi dan kerbau untuk membajak sawah. Setelah tahun 2000 teknologi modern mulai digunakan oleh petani dalam mengolah sawah mereka (Subaedah et al., 2018).

Selain bidang pertanian Desa Bungi juga mengandalkan bidang perdagangan sebagai tumpuan ekonomi bagi masyarakatnya. Hal ini dikerenakan Letak Desa Bungi cukup strategis karena dilalui oleh jalan poros lintas provinsi dan juga terdapat sebuah pasar yang menjadi pusat perekonomian masyarakat. Keberadaan pasar telah memudahkan para pelaku usaha dalam mempublikasikan usaha mereka sehingga dalam waktu yang relatif singkat mereka dapat dikenal oleh konsumen. Jumlah pedagang eceran di Desa Bungi mengalami peningkatan. Pada tahun 2004 jumlah pedagang eceran adalah 147 kemudian pada tahun 2012 menjadi 172 pedagang eceran, sedangkan pedagang besar dan rumah makan tidak mengalami perubahan. Secara umum keberadaan pasar telah membawa pertumbuhan ekonomi yang baik bagi masyarakat disekitarnya yang diindikasikan dengan tingginya pertumbuhan kewirausahaan disekitar pasar.
Selain itu Pinrang tahun 2012 di Desa Bungi juga terdapat usaha di sektor jasa seperti 6 usaha bengkel, 6 usaha jasa service elektronik, 13 tukang penjahit, 6 usaha salon, 3 usaha jasa foto studio, 3 usaha foto copy, dan 1 buah tempat usaha SPBU atau pom bensin. (Badan Pusat Statistik, 2013) Keberadaan usaha tersebut tentunya juga membutuhkan pegawai dalam pelayannya, walaupun jumlahnya tidak banyak tetapi hal ini sudah membuktikan adanya penyerapan tenaga kerja sehingga memberikan dampak terhadap perekonomian yang ada di Desa Bungi.

\section{d. Bidang Kesehatan}

Upaya untuk meningkatkan akses masyarakat terhadap pelayanan kesehatan yang berkualitas, di antaranya adalah dengan meningkatkan akses terhadap pelayanan kesehatan dasar. Peran puskesmas dan jaringannya sebagai institusi yang menyelenggarakan pelayanan kesehatan di jenjang pertama yang terlibat langsung dengan masyarakat menjadi sangat penting. Puskesmas bertanggungjawab menyelenggarakan pembangunan kesehatan di wilayah kerjanya. Keberadaan fasilitas kesehatan (Puskesmas) di Desa Bungi sudah ada sejak tahun 1968 yaitu berupa dua gedung, meskipun fasilitasnya belum memadai.(Mansur, 2019) Kemudian di tahun 1993 dilakukan renovasi beserta pembangunan satu gedung lagi untuk ruangan rawat inap. Saat ini di Desa Bungi terdapat fasilitas kesehatan yaitu Pusat Kesehatan Masyarakat (Puskesmas) sebanyak 1 yang berada di Dusun Bungi dan Pos Pelayanan Terpadu (Posyandu) sebanyak 3 yang berada di Dusun, Bajeng kaluku, Dusun susbater, dan Dusun Bungi.

Untuk mendukung fungsi dan tujuan puskesmas diperlukan sumber daya manusia kesehatan yang sesuai standar profesi dan standar pelayanan. Kinerja dari puskesmas sangat dipengaruhi ketersediaan sumber daya manusia yang dimiliki, terutama ketersediaan tenaga kesehatan. Adapun jumlah tenaga kesehatan yang ada di puskesmas Desa Bungi untuk dokter umum, perawat, bidan sudah cukup 
memadai sedangkan untuk dokter gigi meskipun di tahun 2004 terdapat 1 dokter gigi namun di tahun 2012 Puskesmas Bungi tidak memiliki dokter gigi dan untuk dokter spesialis tidak pernah ada. Selain itu terdapat pula Dukun Bayi terlatih yang merupakan tenaga kesehatan non medis yang telah mendapat pelatihan oleh tenaga kesehatan dan dinyatakan lulus. Dukun bayi diangkat karena adanya kepercayaan masyarakat setempat dan merupakan pekerjaan yang sudah turun temurun. Dukun bayi terlatih ini biasanya bertugas untuk membantu masyarakat dalam proses persalinan. Pada tahun 2006 sampai 2012 karena disebabkan faktor usia dan juga kurangnya minat generasi penerusnya untuk melanjutkan pekerjaan sebagai dukun beranak. (Statistik, 2012).

\section{e. Bidang Sosial}

Pada saat sekarang ini seiring dengan perkembangan zaman dan keterbukaan masyarakat dalam berbagai aspek, menyebabkan kondisi masyarakat di pedesaan tentang cara berpikir, pandangan terhadap kemajuan teknologi mulai lebih terbuka. Terkait pada status sosial pada masyarakat di Desa Bungi yang sebelumya di ukur berdasarkan tinggi rendahnya status kebangsawanan kini mulai diukur pada taraf kehidupan dan tingkat kemapanan hidup masyarakat. Perubahan ini terlihat khususnya sebelum tahun 1990-an Kepala Desa Bungi dijabat oleh seorang bangsawan yang disebut puang, namun pada tahun 1997 Desa Bungi dipimpin oleh Drs. Alhusari latif yang merupakan seorang tokoh pemuda saat itu.

Kini masyarakat Desa Bungi melihat lapisan sosial tertinggi berada pada orang yang memiliki tingkat kemapanan yang tinggi dan orang yang memiliki pendidikan atau jabatan yang lebih tinggi. meskipun telah terjadi pergeseran cara pandang terkait strata sosial namun masyarakat Desa Bungi masih memberikan perlakuan yang baik dan rasa hormat terhadap orang yang memiliki gelar puang. Perlakuan tersebut biasanya pada setiap acara yang diadakan masyarakat makanan yang disajikan di atas baki.

Dalam Hubungan sosial masyarakat Desa Bungi sistem gotong royong masih tetap berlaku meskipun dalam beberapa hal sudah tidak terlihat lagi. Ditahun 80an sampai 90an masyarakat Desa Bungi masih mau untuk bergotong royong menyumbangkan tanahnya untuk membangun jalan desa akan tetapi memasuki tahun 2000an hal tersebut sudah tidak ada lagi. Dalam hal pertanian sitem gotong royong sudah digantikan dengan sistem upah.

Walaupun terjadi perubahan pada sebagian besar sistem gotong royong yang ada di kehidupan masyarakat, penduduk Desa Bungi masih memepertahankan gotong royong ketika ada acara yang dilakukan oleh anggota masyarakat. Masyarakat Desa Bungi biasanya dengan sukarela akan datang membantu seperti pada acara pernikahan, Aqiqah, acara takziyah dan acara pesta lainnya sehingga pemilik acara tidak perlu menyewa jasa juru masak ataupun jasa pengantar undangan untuk mengerjakan hal tersebut.

\section{E. Kesimpulan}

Sejak tahun 1980 sampai tahun 2012 Desa Bungi telah mengalami berbagai perkembangan khususnya dibidang pemerintahan, bidang ekonomi, bidang pendidikan, bidang kesehatan dan bidang sosial. Perkembangan yang dialami Desa Bungi tidak terlepas dari peran pemerintah desa dalam menjalankan pemerintahannya dan juga bantuan dari masyarakat Desa Bungi.

\section{F. Daftar Pustaka}

Badan Pusat Statistik. Kecamatan Duampanua dalam Angka 2004. Kabupaten Pinrang.

Badan Pusat Statistik. Kecamatan Duampanua dalam Angka 2006. Kabupaten Pinrang.

Badan Pusat Statistik. Kecamatan Duampanua dalam Angka 2007. 
Kabupaten Pinrang.

Badan Pusat Statistik. Kecamatan Duampanua dalam Angka 2008. Kabupaten Pinrang.

Badan Pusat Statistik. Kecamatan Duampanua dalam Angka 2009. Kabupaten Pinrang.

Badan Pusat Statistik. Kecamatan Duampanua dalam Angka 2010. Kabupaten Pinrang.

Badan Pusat Statistik. Kecamatan Duampanua dalam Angka 2011. Kabupaten Pinrang.

Badan Pusat Statistik. Kecamatan Duampanua dalam Angka 2012. Kabupaten Pinrang.

Badan Pusat Statistik. Kecamatan Duampanua dalam Angka 2013. Kabupaten Pinrang.

Latif, A., 2018 wawancara [Interview] (24 januari 2018).

Nurcholis, H., 2011. Pertumbuhan dan Penyelenggaraan Pemerintahan Desa. Jakarta: Erlangga

Mansur, N., 2019 wawancara [Interview] (5 April 2019).

Sjamsuddin, H., 2007. Metodologi Sejarah.Yogyakarta: Penerbit Ombak.

Thamrin, M., 2018 wawancara [Interview] (26 januari 2018). 